\title{
The Provision of Rest Areas on Non Toll Roads in Indonesia through Corporate Social Responsibiliy
}

\author{
Hendra Hendrawan $^{1}$ and Winni Sharfina ${ }^{2}$ \\ Institute of Road Engineering. A.H Nasution No. 264 Ujung Berung Bandung, Indonesia
}

\begin{abstract}
Rest Areas on non toll roads are road equipment that is not directly related to road users whose primary function is to reduce the number of accidents caused by driver and vehicle fatigue. This is in accordance with the agenda of the National General Plan of Road Safety (RUNK) to provide preventive infrastructure against potential accidents. To provide safe, convenient, secure, and sustainable rest areas, the government is faced with funding constraints. In the implementation, the construction of rest areas require funds that are not little, especially for land procurement and physical infrastructure development. For that reason, funding alternative is needed through Corporate Social Responsibility. This paper aimed to examine the feasibility of rest areas development through Corporate Social Responsibility by considering the aspect of legality and potential problems. The method used was literature review which included the aspects of feasibility, legality, and mechanism. The results showed that the rest areas can be part of Corporate Social Responsibility. The results of the study also indicated the need for additional tools in the form of regulations and guidelines to govern the partnership pattern so that development through this mechanism is well-running, supervised, and accountable
\end{abstract}

Keywords: Corporate Social Responsibility, Feasibility, Non-toll Road Rest Area

\section{Introduction}

Various efforts are made by the government to reduce the number of accident, in term of regulation, infrastructure development/ improvement (physical and non-physical), as well as counseling/ workshops. Efforts made by the government through regulation include regulation to use main light in the daylight for motorcycle, use standard helmet, use proper equipment, and regulation of vehicle and road functionality. In infrastructure aspect, the government has tried to implement efficient and effective budgeting through structuring priority scale for road handling by using reliable and environmentally friendly technology, as well as traffic engineering management to fulfill Minimum Service Standards (SPM) for road service and system. As for the current efforts of counseling/ workshop, the government has delivered advertisement for public and given some trainings to the public to understand, and be able to implement safety traffic practices.

The government has set "seven directions and three strategies" to realize safety road (Indonesia, 2010). Those seven directions include the formalization and standardization of traffic accident management, a guarantee system for the settlement of losses due to traffic accidents, road safety education, law enforcement with deterrent effect, provision of sustainable funding to improve road safety, strict driving rights, effective road safety organization supported by accurate information system, and provision of traffic facilities and infrastructure that meet safety eligibility standards. To support those seven directions, the government has determined three strategies for road management, which were alignment of direction and commitment of road safety by coordinating five pillars inclusively, road safety implementation using cost efficiency approach through curative and preventive measures, and road safety system that can accommodate human error and human body vulnerability (Indonesia, 2010). 
Efforts to support the direction of the road safety policy, especially in the provision of traffic facilities and infrastructure that meet road safety standards, are preventive, and accommodate human error and human body vulnerability is through the provision of road equipment that can reduce the potential for accidents. One of the road equipment what is meant is a rest area (Pangihutan and Hendrawan, 2016).

The regulation regarding obligation to rest for drivers is provided in Act of Republic Indonesia number 22 year 2009 on Road Traffic and Transportation, Part Three Working Time of the Driver, Article 90. It is mentioned that the driver of a public motor vehicle shall rest for a minimum of half an hour after driving for 4 (four) consecutive hours or rest for 1 (one) hour after driving for 12 (twelve) hours a day (Indonesia, 2009a). To support the regulation and to facilitate the driver to rest optimally, the provision of safe, comfortable, safe, and sustainable rest areas is a must (Hendrawan et al, 2016).

The operation of rest areas on toll roads shall refer to toll road legislation, including technical guidance on the planning and management of rest areas issued by the Toll Road Regulatory Agency (BPJT) as an institution that has half of the government's authority to organize, manage and supervise the operation of toll roads (Indonesia, 2005). The operation of rest areas on toll roads is generally carried out by the Partners of Toll Road Operators (BUJT) that follow the auction process. The form of cooperation between BUJT with partners is with the mechanism of Build Operate Transfer (BOT) or Build Operate Own (BOO) (Nugroho et al, 2016).

The operation of rest areas on public roads (non-toll roads) shall be subject to general road legislation and regulations and shall be within the authority of the road operator. For the planning of rest areas on public roads, the R \& D Agency of the Ministry of Public Works and Housing has developed the guidelines and is expected to be used as a reference by all road operators (Hendrawan et al, 2016).

The provision of rest areas, although supported by the technical regulations and guidelines, are still confronted with several constraints such as management and funding for development, operations and maintenance. For management, Nugoro et al (2016) recommended an institutional alternative and minimum service standards. An alternative choice of management policy is that its implementation should be carried out by road operators in accordance with their authority or through the cooperation of the central and regional governments. The recommendation of organizational structure of the management institution is Technical Implementation Unit (UPT) led by echelon-level IVa officials. Those recommendations are selected based by considering the simplification of organizational structure, resource efficiency, and legality support in which the obligation of providing and managing rest areas is in the hand of the road operators.

Another problem is funding. The construction of a rest area will cost a lot for land acquisition, facilities development and management. On the other hand, road operators are still faced with funding constraints that are more focused on increasing connectivity for strengthening competitiveness and increasing national road stability with the goal of reducing travel time on the main corridor from 2.7 hours per $100 \mathrm{~km}$ to 2.2 hours per $100 \mathrm{~km}$, an increase in road service from 101 billion vehicles per $\mathrm{km}$ to 133 billion vehicles per $\mathrm{km}$, and increase facilitaties of local roads to support the region from $0 \%$ to $100 \%$ (Indonesia, 2015). With the limited funds, the role of the private sector through various corporate social policies/Corporate Social Responsibility (CSR) scheme is required.

CSR can simply be defined as the responsibility of a profit-oriented company to all stakeholders to build a holistic, institutional and sustainable social economy of the region (Suharto, 2006 and Kartini, 2013). These stakeholders include all stakeholders who contribute and influence the output (of goods or services or the end result and desired objectives) of a company (primary stakeholders), and stakeholders who are directly or indirectly influenced by the activities of the company (scondary stakeholders) (Post et all, 2002). Based on these stakeholders, social responsibilities include internal environmental responsibility or operational responsibilities and external environmental social responsibility or citizenship responsibilities (The Globe Scan in Kartini, 2013). Internal responsibilities include the protection of health and safety for employees, fair treatment, protection of the work environment, the fulfillment of tax obligations for the company, the sale of qualified and 
affordable products, and so forth. The external responsibilities include responsiveness to community needs, environmental protection, human rights protection, community development, and support and implementation of government policies to improve community welfare (Kartini 2013).

Machmud (2015) has undertaken a review of the use of CSR funds as an alternative to local development financing through the analysis of institutional and stakeholder involved, analysis of regulatory and policy, analysis of CSR implementation forms, and analysis of sources and funding patterns. There are several suggested steps to optimize alternative financing sources of local development through CSR, such as mapping of CSR programs by region, strengthening of village institutions, and establishing CSR forums. In addition, $90 \%$ of companies recommend synchronization activities with the government and $60 \%$ of companies recommend the design of CSR programs.

CSR programs have been widely implemented for the development of public infrastructure such as the provision of clean water, sanitation, irrigation, roads, education, and health. In order for a project to be implemented properly, that is, to achieve the expected goals efficiently and effectively, a feasibility analysis is required. Based on this, the study has two objectives:

a) Analyze the financial feasibility of rest area's construction through CSR scheme.

b) Analyze legal aspect and CSR mechanism of rest area's contruction.

\section{Methodology}

This study used descriptive qualitative method to create a picture of the situation with the aim to answer a problem. To address these problems, the study used secondary data obtained from various literatures. The literature included aspects of legal, implementation/ operation, problems, and evaluation of CSR implementation. Related articles were collected, recorded, and verified and then analyzed (using triangulation) against other data sources to remain relevant to the study. Broadly speaking, the method to answer the purpose of study can be seen in Figure 1.

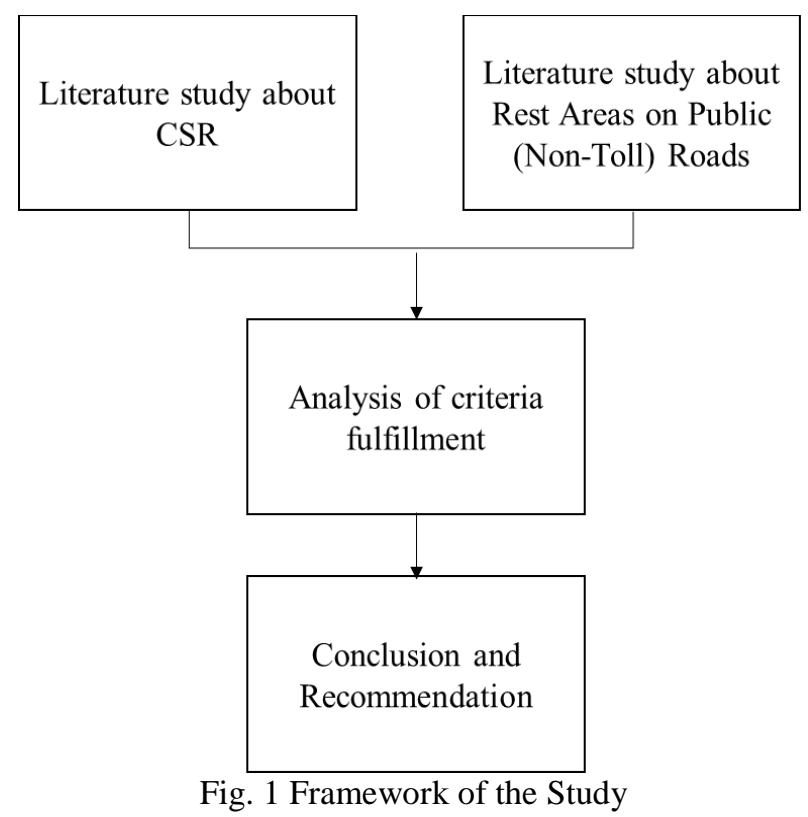

Literature study was done to gain information or theories relevance to the topic. Through literature study, it is expected to know and examine the problems, experiences, and theories that can answer the problem. In this study, there were four aspects being studied, such as legal, benefits of providing a rest area (in terms of economic, social, and environmental aspects), stakeholder identification, benefits for 
the corporates, and finally the mechanism of CSR implementation for financing rest area. Each aspect was analyzed comprehensively to be drawn conclusions and made recommendations to be followed up through policy or further study.

The purpose of the literature study is to evaluate the fulfillment of the criteria required for rest areas funded through the CSR program, without causing new problems either from the side of the regulation or the implementation stage. Relevant and current references are key to the literature study. The results of literature study were then used to draw conclusions on how far can regulations/legal support CSR, and how can CSR principles be applied to support public services through the construction of rest areas on public roads that meet standards to address accident issues.

\section{Result And Discussion}

Feasibility analysis is part of efforts to assess whether or not an action is feasible in the form of direct investment (through infrastructure development) or indirect investment (through lending or funding). The purpose of the feasibility analysis is to reduce the risk of inefficiency or ineffectiveness in order to obtain results or economic/social benefits expected within a specified time span according to plan.

Feasibility analysis can be done at various stages of the program or activity cycle. For example in selecting location, financing for development, selecting technology and resource (material and labor), and others. The bigger the scale of investment the more important this analysis is done which starts from the preliminary stage up to the whole stage of the activity. There are several factors that influence the feasibility study including the amount of cost required, the degree of uncertainty or risk, and the complexity of elements affecting the activity (PIMAC, 2008).

Based on the above explanation, there are at least three feasibility analysis need to be undertaken for the construction of a rest area, ie location selection, financing scheme, impact or benefit to the triple bottom line (profit, people and planet) and management (Elkington, 1997). The analysis is required with a variety of considerations:

- Location selection determines the level of efficiency and effectiveness of providing rest areas and reduces the potential risks of future problems.

- Provision of rest areas can be an unprioritized activity in realizing the road of safety. Limited funding is a constraint to development. Therefore, it is necessary to provide financing alternatives supported by strong regulation and clarity of the mechanism.

- Feasibility analysis for the provision of infrastructure becomes very important for a big scale investment. The construction of a rest area requires considerable investment value for land acquisition and construction. The value is affected by the type of rest area and the additional facilities inside.

- The management system affects the efficiency of resources and the service effectiveness. It should be noted that there are several facilities that must be provided free of charge, ie toilets, parks, mosques, and parking areas. Thus required a slim institutional form to suppress the necessary resources.

From the above description, the feasibility analysis of financing is an important part to support the construction of rest areas. One of the financing sources offered is through the CSR program. There are several things need to be analyzed before justifying that the construction of a rest area is feasible to be financed:

- Legal aspect;

- Benefits and supports upon sustainability issues;

- Stakholders involves and role-sharing; and

- Implementation mechanism. 


\subsection{Legal Aspect of Financing Rest Area Through CSR Scheme}

The provision of public infrastructure falls under the authority of the Government. However, not all public infrastructure becomes the responsibility of the government, especially in relation to efforts to overcome the externalities or negative impacts to the community from the corporate/ company activities. These impacts can be economic, social and/ or environmental. For this reason, CSR schemes are mandatory in a matter of handling negative impacts and regulatory compliance of the existence of corporate activities, and may be voluntary on the other matter. Obligation of CSR implementation in Indonesia is arranged in several regulations such as:

1. Act of Republic of Indonesia number 22 year 2001 on Oil and Gas Article 11 paragraph 3 and Article 40 paragraph 5.

2. Act of Republic of Indonesia number 40 year 2007 on Limited Liability Company/ Incorporated Article 1 number 3, and Article 74.

3. Act of Republic of Indonesia number 25 year 2007 on Capital Investment Article 15 letter b, and Article 16.

4. Act of Republic of Indonesia number 32 year 2009 on the Protection and Management of the Environment Article 68.

5. Government Regulation no. 47 year 2012 on Incorporated Social and Environment Responsibility

6. Regulation of the Minister of State-Owned Enterprises number PER-08/MBU/2013 On the Fourth Amendment to The Regulation Of The Minister Of State Owned Enterprises. PER05/MBU/2007on Partnership Program of State-Owned Enterprises with Small Business and Community Development. CSR regulations can be seen in Articles 1 and 2.

Some important notes regarding those regulations are:

1. Obligation to implement CSR is not onlu limited to the company, although there are special regulations requiring CSR for companies that manage and utilize their resources or activities that impact the carrying capacity of the environment (Indonesia, 2007a and Jalal, 2009).

2. CSR are not limited only to large companies, but for all companies to minimize impact (Indonesia, 2007b and Kartini, 2013).

3. CSR are not limited to core business, but can be carried out outside the core business after handling or minimizing the impact of the company's activities (Indonesia, 2001, Indonesia, 2007b, and Jalal, 2009).

4. CSR are not limited to direct actors but also include companies that are not directly involved such as banks, suppliers, and even business partners. Thus CSR activities are not limited to direct handling activities, but promoting and marketing CSR activities is one form of CSR activity itself (Kartini, 2013).

5. A company is not deemed to engage in CSR activities if there are any regulations or laws violated (Franc, 2006).

In its implementation, Rahmatullah (2012) suggested a special regulation that arrange the Government and corporate partnerships to manage CSR programs.

\subsection{Benefits and Supports for Sustainability Issues}

CSR, regarding to Watrick and Cochran (1985) in Kartini (2013), has to meet three principles:

- Corporate Social Responsiveness, which is responsive to the social issues. This principle is mandatory to gain support from the government and community.

- Corporate Governance, which is success in earning profit or benefit from its activity. CSR is no longer seen as a burden, but is part of the implementation of holistic marketing through the process of enhancing internal resources, product communications and values, consumers 
protection with ethical, environmental, legal, and social contexts to improve common wellbeing, and build mutual cooperation with various stakeholders.

- Corporate Citizenship which is doing various deeds as good citizens.

Carrol (1979) in Kartini (2013) said that CSR concepts have to include four components:

- Economic Responsibilites. Responsibility to produce goods or services to obtain benefits or profits for the company.

- $\quad$ Legal Responsibilities. Responsibilities to obey regulations/laws.

- $\quad$ Ethical Responsbilities. Responsibility to produce goods or services that are beneficial and /or valuable to the community and carry out good business ethics.

- Discretionary Responsibilities. Responsibility to provide benefits for the surrounding community.

Those three principles and components are the foundation in running the CSR which is also an integral part of sustainable development concept (Franck et al, 2006). Thus the fulfillment of sustainable principles covering economic, social, and environmental aspects, is a must to assess the feasibility of constructing a rest area through a CSR scheme.

To answer these needs, the rest area are developed through the concept of Road Side Station (APJ). Rest areas with APJ concept are aimed to reduce the number of traffic accidents and be used as a center of rapid reaction units for road preservation and economic improvement of local communities. There are five principles of rest area planning to support the concept of APJ (Indonesia, 2016), which are:

- Compliance with laws and requirements of road and building engineering.

- $\quad$ Security, safety, and convenience for road users and rest area users.

- The needs of road users, road operators and local communities

- Conformity of rest area purpose with sectoral and regional master plan development.

- Involvement of all stakeholders in government, private and community.

These five principles are translated into planning activities from location selection to facilities/amenities determination and capacity. Related to the process of location selection there are things that must be considered (Indonesia, 2016):

- Safety and ease of road users and rest area users.

- $\quad$ Suitability of location with spatial plan and environmental permit.

- $\quad$ Sustainability and efficiency of providing rest areas.

- $\quad$ Suitability of the location with the development plan.

The facilities provided are rest areas, road management posts, emergency response posts, information centers, public facilities, and local economic incubator. Each requirement for the type and capacity of the facility is analyzed with considering the minimum limit that needs to be provided within a reasonable standard (humane).

Kotler and Lee (2005) mentioned six categories for CSR activities, which are cause promotions, cause related marketing, corporate societal marketing, corporate philantropy, community volunteering, dan social responsible business practise. The categories that when are associated with activities in rest area with APJ concept are:

1. Cause Promotions. Company raises awareness and social issues, such as environmental conservation, culture, and traffic safety by utilizing information facilities.

2. Cause Related Marketing. Marketing related to social activities. The company engages in social activities by donating its income to social activities. For example providing free health care or providing a drink or food that can increase endurance or restore the condition of the driver. 
3. Corporate Social Marketing. Company conducts campaigns to improve health, safety (including roads and workplaces), environmental sustainability, and community participation in social activities.

4. Corporate Philantropy. Company engages in direct social activities either in the form of providing services or free financial assistance. For example provide financial assistance to farmers or craftsmen who sell local products.

5. Socially Responsible Business Practice. Company may undertake activities that include the provision of facilities that meet safety, security, and environmental standards.

Table 1. shows the support of providing a rest area with the concept of road side station on sustainable principles. The benefits and support of sustainability provision in Table 1 can be achieved with optimal results by identifying the needs, stakeholders involved, and the benefits or outcomes to be achieved by the company. With such identification, the company can choose exactly the type of activities to be performed in accordance with the impact of the activity, the product being marketed or the benefits to be achieved.

TABLE I: Rest Areas with APJ Concept With Sustainability Principles

\begin{tabular}{|c|c|c|c|}
\hline Stakeholder & Economy & Social & Environment \\
\hline Internal & $\begin{array}{l}\text { - Increase sales volume } \\
\text { and market share } \\
\text { - Attract potential } \\
\text { investors }\end{array}$ & $\begin{array}{l}\text { - Improve communication and social } \\
\text { interaction with the community } \\
\text { - Improve the company's positive } \\
\text { image } \\
\text { - Gain support and improve } \\
\text { relationships with communities and } \\
\text { governments } \\
\text { - Achieve award }\end{array}$ & $\begin{array}{l}\text { - Increase happiness and } \\
\text { comfort in working, } \\
\text { psychologically and } \\
\text { emotionally. } \\
\text { - Maintain qualified } \\
\text { resources }\end{array}$ \\
\hline External & 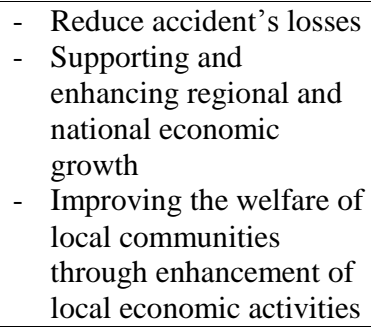 & 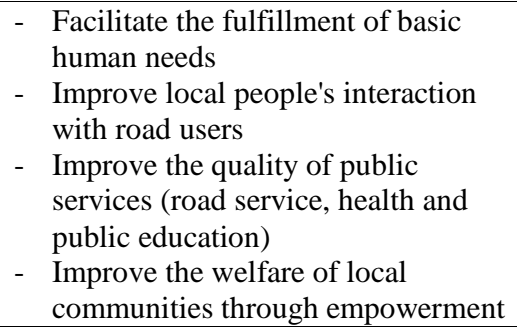 & $\begin{array}{l}\text { Reduce the risk of natural } \\
\text { disasters }\end{array}$ \\
\hline
\end{tabular}

\subsection{Stakeholders and Role Sharing}

Identification and dialogue among stakeholders is an important part to be implemented in order for CSR schemes to work properly (Franc, 2006). Stakeholders may come from internal/ inside actors or external/outside actors (Kasali in Wibisono, 2007). For the rest area with authority on the road operators (government), the internal stakeholders are all levels or organizations within the government that influence the decision or gain impacts or benefits from the rest area. External stakeholders are companies, local communities, social institutions and road users who directly or indirectly contribute, be affected or receive benefits from the presence of rest areas.

Based on the CSR concept explained above, the stakeholders who need to be encouraged to invest in the rest area are companies that have an impact on traffic or community whose economic activities depend on interaction with road users. For example, automotive companies, that are part of the supply chain, contribute to an increase in the number private motor vehicles. The impact of their marketing activities is related to an increase in traffic volume and under certain conditions the potential for accidents may occur. In other areas, toll road developers can lead to a decrease in local people's incomes selling local souvenirs (in non toll roads). 
TABLE II: Role of Sakeholders in Organization

\begin{tabular}{|c|c|c|c|c|}
\hline \multirow{2}{*}{$\begin{array}{c}\text { Stages of CSR } \\
\text { Program }\end{array}$} & \multicolumn{4}{|c|}{ Stakholders' Roles } \\
\hline & Company & Government & \begin{tabular}{|c|} 
Community \\
\end{tabular} & Istitution/ Organization \\
\hline Planning & $\begin{array}{l}\text { - Helps identify } \\
\text { types of CSR } \\
\text { activities related } \\
\text { to impacts } \\
\text { - Prepare pogram } \\
\text { and development } \\
\text { funding plan }\end{array}$ & $\begin{array}{l}\text { - Provide guidelines for } \\
\text { reast area's planning } \\
\text { - Facilitate the } \\
\text { completion of } \\
\text { licensing and } \\
\text { administration } \\
\text { - Provide input and } \\
\text { assistance in the } \\
\text { planning process }\end{array}$ & 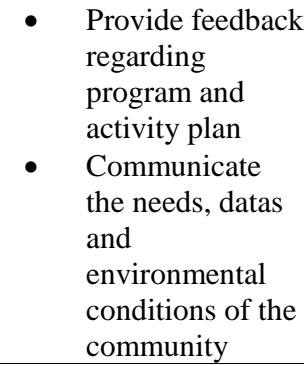 & $\begin{array}{l}\text { - Help convey the concept } \\
\text { of a management plan } \\
\text { that meets the standards } \\
\text { - Establish minimum } \\
\text { service procedures and } \\
\text { standards } \\
\text { - Develop program and } \\
\text { plan for the management } \\
\text { activities }\end{array}$ \\
\hline Implementation & $\begin{array}{l}\text { - Undertake the } \\
\text { construction of } \\
\text { rest area and its } \\
\text { facilities } \\
\text { Implement } \\
\text { CSR activities } \\
\text { to benefit the } \\
\text { company }\end{array}$ & 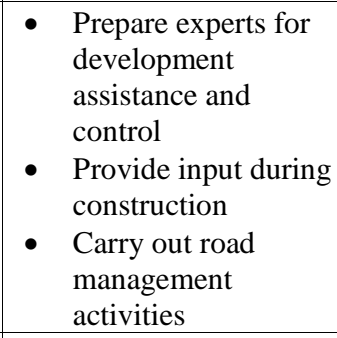 & $\begin{array}{ll}\text { - } & \text { Conduct activities } \\
\text { - } & \text { Receive benefits } \\
\text { of the facilities }\end{array}$ & $\begin{array}{l}\text { - Manage rest areas } \\
\text { including facilities and } \\
\text { utilities inside. } \\
\text { - } \quad \text { Provide services to the } \\
\text { community } \\
\text { - Manage CSR activities } \\
\text { - Manage and control } \\
\text { income and expenses }\end{array}$ \\
\hline Controlling & $\begin{array}{l}\text { Monitor the } \\
\text { construction } \\
\text { results and } \\
\text { CSR activities }\end{array}$ & $\begin{array}{l}\text { Control the use of } \\
\text { rest areas } \\
\text { appropriately and } \\
\text { does not result in } \\
\text { disruption or } \\
\text { violation of rules, } \\
\text { values and } \\
\text { procedures } \\
\text { Help resolve } \\
\text { disputes or issues } \\
\text { that arise }\end{array}$ & $\begin{array}{l}\text { - Control the } \\
\text { implementation of } \\
\text { CSR activities } \\
\text { Provide support } \\
\text { through } \\
\text { partnerships with } \\
\text { companies }\end{array}$ & $\begin{array}{l}\text { - Control the management } \\
\text { of rest areas in order to } \\
\text { meet minimum service } \\
\text { standards } \\
\text { - } \quad \begin{array}{l}\text { Supervise the facility to } \\
\text { match its designation }\end{array} \\
\text { - Monitor and control the } \\
\text { utilization of income or } \\
\text { funds obtained } \\
\text { Control the management } \\
\text { of rest area }\end{array}$ \\
\hline
\end{tabular}

Furthermore, from all stakeholders involved, identification of the roles of each stakeholder was identified. Kartini (2013) suggested the establishment of CSR Planning Agency, CSR Implementation Agency and CSR Controlling Agency. Each of these agencies is represented by elements of government, companies, communities, and management institutions. Each of these stakeholders can also form a substructure of each organization to run its role. The role of each stakeholder can be seen in Table 2.

Regarding the organizational structure for the management of rest areas (implemented) by the government, the government can establish Technical Implementation Unit (UPT). If the management will be handed over to the community, the structure can be in a form of a cooperative/union. The whole structure of the organization/institution needs to be contained within a main/parent organization that will set the pattern of partnership and role clearly.

In organazing rest area, active participation and cooperation of all stakeholders is needed. Through active participation, the activities undertaken by the company should be in accordance with the needs of the community or current social issues. Companies can plan their activities well, including the plan of facilities that need to be provided in rest area.

\subsection{Implementation Mechanism}

Wang et al (2017) mentinoned that there were four aspects that encouraged implementation of CSR in some countries:

1) regulations that force CSR programs to be implemented

2) a desire to increase profit, increase competitiveness, motivate workers, and enhance corporate image, etc. (Internal factors) 
3) encouragement from outsiders or community demands

4) Culture or local values

As for the CSR implementation model, there are generally four models (Saidi and Abidin, 2004):

1) The Company runs its own CSR program without an intermediary. The company can form its own organizational structure of planner, executor, and controller, or assign one of its senior officials.

2) The company establishes a foundation or social organization.

3) The company engages in partnerships with governments, social institutions (NGOs), educational institutions, health institutions, and others.

4) The company joins a consortium, or a member within an established social institution.

Of the four partnership models, the pattern of where the implementation is a government obligation, the partnership pattern is a better CSR model. However, in practice, to prevent counterproductive or semi-productive partnerships, there are three principles that must be implemented to build a good partnership pattern (Wibisono, 2007):

1) Equity. Stakeholders respect and trust each other,.

2) Transparency. Stakeholders are open to information and financial management.

3) Mutually profitable. Stakeholders benefit all parties.

It requires cooperation of all stakeholders to build partnerships that meet these three principles. As mentioned earlier, stakeholder cooperation is an important part of CSR implementation. Each stakeholder must be able to carry out their roles and duties responsibly and in synergy with each other. In order to synergize it requires synchronization between the government and the company in the stages of program implementation.

Hurairah (2008) stated that there were six stages in the implementation of community development which included needs identification, action plan, implementation, monitoring and evaluation, completion or delivery of the program, and post-program follow-up plan. As for the implementation stage of the rest area there are several stages that must be implemented:

1) Needs identification.

Selection of rest area based on the principles and criteria specified in the rest area guideline.

2) Stakeholders identification.

Considerations in choosing stakeholders include (TTPS, 2010):

- The proximity of the rest area.

- The relevance of the CSR program with the impact or expected benefits.

- Magnitude. The direction of the plan or the indirect benefits of the CSR program.

3) Institutional Arrangement.

Institutions are needed as part of sustainability and to clarify the roles of each stakeholder.

Each stakeholder establishes a separate organizational structure to implement and control the role that has been agreed.

4) Planning the Programs.

Involving all stakeholders through a partnership. Enhance active participation to synergize programs according to the role of each stakeholder including funding related.

5) Program Implementation.

Implementation stage from development, utilization and operation, and maintenance.

6) Evaluation and Monitoring

Controlling and supervising program implementation to fit the plan. Identify problems and obtain feedback on activities that have been implemented.

7) Reporting 
Reporting all the duties and responsibilities of program implementation to be followed up.

The next stage after reporting is the rearrangement of plan or resume in stage 4. To measure the performance of CSR implementation, there are eight indicators that can be used (Kartini, 2013):

1) Leadership. There is a commitment of the government and company leaders in supporting the program of rest area and CSR activities.

2) Transparency and accountability. Government and companies are open in the use of funds and reporting the implementation and results achieved.

3) Proportion of aid. Allocation of funds issued matches with the needs.

4) Area coverage. CSR programs can reach the target beneficiaries who are expected to be road users and local communities.

5) Planning, monitoring and evaluation. Planning includes the involvement of all stakeholders, and conformity with local culture and wisdom. Monitong and evaluation includes policies and clear role sharing.

6) Coordination of stakeholders. There is a clear mechanism for coordination among stakeholders.

7) Sustainability. There is over the role of the company to the community, a sense of belonging, and participate in maintaining existing facilities.

8) Outcome. The programs that have been implemented have real impacts on the community, the number of accidents decreases, the public services performance of the roads increases, local community is more empowered and welfare improvements occur.

\section{Conclusion}

Based on the above study, it can be concluded that the provision of rest areas can be organized through CSR programs based on sustainability, benefits, and support for community empowerment. The CSR program for the provision of public facilities already has a clear legal aspect, and in its implementation there are several examples of cases, as well as guidance of its management. In order for CSR implementation to run optimally, two important things to note are the identification of stakeholders and the existence of technical guidelines from the road operators. The guidelines set the partnership pattern that clearly divides the role of each stakeholder. The technical guidelines are jointly prepared by the government and stakeholders.

\section{Acknowledgement}

The Authors would like to express sincere gratitude to the Head of Institute of Road Engineering and the Head of Traffic Laboratory who have supported the research about management of rest areas in non-toll road using APJ concept.

\section{References}

[1] Damopoli, Farrah Ch., Kawatu, Paul A.T., and Tumbol, Reiny A. (2013) Faktor-faktor yang berhubungan dengan kelelahan kerja pada supir bis trayek Manado Amurang di Terminal Malalayang Manado..

[2] Engkington, J.1997. Cannibal With Forks: The Triple Bottom Line of 21 st Century Business. Capstone Oxford

[3] Jalal. 2009. Kesalahpahaman tentang Tanggung Jawab Sosial Perusahaan. Diperoleh dari https://csrlingkunganindonesia.wordpress.com/artikel-csr-lingkungan/jalal/ [Diakses 22 September 2017]

[4] Fadel, Muhammad., Muis, Masyitha., Russeng, Syamsiar. 2014. Faktor yang Berhubungan dengan Kelelahan Kerja Pengemudi Pengangkutan BBM di TBBM PT. Pertamina Parepare.Universitas Hasanuddin

[5] Franc, Pavel., Nezhyba, Jiri., Heydenreich, Cornelia. 2006. Taking Corporate Social Responsibility Seriously. Environmental Law Sevice 1st Edition. 
[6] Hendrawan, H., Pangihutan, H. Nugroho, A., Parbowo. 2016. Laporan Akhis Pendampingan Teknis Anjungan Pelayanan Jalan. Bandung: Pusjatan

[7] Hurairah, Abu. 2008. Pengorganisasian danPengembangan Masyarakat. Bandung: Humaniora

[8] Kartini, Dwi. 2013. Corporate Social Responsibility Transformasi Konsep Sustainability Management Dan Implementasi di Indonesia. Bandung: Refika Aditama.

[9] Kotler, Philip and Lee, Nancy. 2005. Corporate Social Responsibility: Doing The Most Good for Your Company and Your Cause. John Wiley\&Sons.

[10] Lum, H., Reagen, J.A. 1995. Interactive Highway Safety Design Model: Accident Predictive Module. Public Roads Magazine, 59 (2): 1-6

[11]Machmud Senen. 2015. Kajian Pemanfaatan Dana Corporate Social Responsibility Sebagai Alternatif Sumber Pembiayaan Pembangunan Daerah. Jurnal Ekonomi, Bisnis \& Entrepreneurship Vol. 9 No. 1 April 2015, 29-44.

[12] Nugroho, A., Hendrawan, H., Pangihutan H. 2016, dan Sharfina, Winni. Naskah Kebijakan Anjungan Pelayanan Jalan. Bandung: Pusjatan

[13] Pangihutan, Harlan., and Hendrawan, Hendra. 2016. Model Pengelolaan Tempat Istirahat Pada Jalan Non Tol. Jurnal Jalan dan Jembatan. Volume 33 No. 2, Juli-Desember 2016. 127:139

[14] PIMAC, 2008. General Guidelines for Preliminary Feasibility Studies (fifth edition).

[15] Post, James, E, and Lawrence, Anne T, and Weber, James, 2002. Business and Society: Corporate Strategy, Public Policy, Ethics, tenth Edition. McGraw Hill

[16] Rahmatullah. 2012. Model Kemitraan Pemerintah dengan Perusahaan Dalam Mengelola CSR: Studi Kasus Kota Cilegon. Jurnal Informasi, Vol.17. No.01: 36-47

[17] Republic of Indonesia. 2001. Law Number 22 Year 2001 Concerning Petroleum and Natural Gas. Jakarta: State Secretariat

[18] Republik Indonesia, 2005. Goverment Regulation Number 15 Year 2005 Concerning Tol Roads. Jakarta: State Secretariat

[19] Republik Indonesia, 2006. Goverment Regulation Number 34 Year 2006 Concerning Roads. Jakarta: State Secretariat

[20] Republik Indonesia, 2007. . Law Number 40 Year 2007 Concerning Limited Liability Company. Jakarta: State Secretariat.

[21] Republik Indonesia, 2007b. Law Number 25 Year 2007 Concerning Capital Investment Jakarta: State Secretariat.

[22]Republik Indonesia, 2009a. Law Number 22 Year 2009 Concerning Road Traffic and Transportation. Jakarta: State Secretariat.

[23] Republik Indonesia, 2009b. Law Number 32 Year 2009 Concerning Environmental Protection ana Management. Jakarta: State Secretariat

[24] Republik Indonesia, 2010. Rencana Umum Nasional Keselamatan (RUNK) Jalan 2011-2035. Jakarta.

[25] Republik Indonesia, 2012. Government Regulation Number 47 Year 2012 Concerning Social and Environmental Responsibility of Limited Liability Company.

[26] Republik Indonesia, 2013. Regulation of Ministry of State-Owned Enterprises Number. PER-08/MBU/2013 Tahun 2013 Concerning Forth Amendment of Ministry of State-Owned Enterprises Number PER-05/MBU/2007 Concerning Partnership Program State-Owned Enterprises with Small Business and Community Development Program. Jakarta..

[27] Republik Indonesia, 2015. Rencana Strategis Kementerian Pekerjaan Umum dan Perumahan Rakyat Tahun 2015 2019. Jakarta: Ministry of Public Works and Housing.

[28] Republik Indonesia, 2016. Draft Pedoman Perencanan Tempat Istirahat Pada Jalan Umum (R4). Bandung: Institute of Roads Engineering. Ministry of Public Works and Housing

[29] Saidi, Zaim,. Abidin, Hamid. 2004. Menjadi Bangsa Pemurah: Wacana dan Praktek Kedermawanan Sosial di Indonesia. Jakarta: Piramedia

[30] Sari, Windy Pranita., Mahyuni, Eka Lestarai., Salmah, Umi. 2015. Faktor-faktor Yang Mempengaruhi Potensi Kecelakaan Kerja Pada Pengemudi Truk di PT Berkatnugraha Sinarlestari Belawan Tahun 2015. Univesitas Sumatera Utara. Medan 
[31] Suharto, Edi. (2006). Membangun Masyarakat Memberdayakan Rakyat Kajian Strategis Pembangunan Kesejahteraan Sosial dan Pekerjaan Sosial. Bandung : Aditama.

[32] Tjakranata, Lanny H. 1996. Tesis. Pengaruh Kelelahan Pengemudi Terhadap Frekuensi Kecelakaan Lalu lintas (Studi Kasus: Pengemudi Bus di Jalan Tol Jakarta-Cikampek)

[33] TTPS. 2010. Buku Panduang Tanggung Jawab Sosial Perusahaan (Corporate Social Responsibility-CSR) Sebuah Potensi Alternatif Sumber Pendanaan Sanitasi. Tim Teknis Pembangunan Sanitasi

[34] Transport Accident Commission. 2017. Avoiding driver fatigue. (http://www.tac.vic.gov.au/road-safety/safe-driving/tips-and-tools/fighting-fatigue, diakses 25 September 2017)

[35] Umyati, Ani., Yadi, Yayan Harry., Sandi, Eka Setia Norma. 2015. Pengukuran Kelelahan Kerja Pengmudi Bis dengan Aspek Fisiologis Kerja dan Metode Industrial Fatique Research Commitee (IFRC). Seminar Nasional IENACO.

[36] Wang Fenghua., Lam, Mohica,. Varshney, Sanjay. 2017. Driving Mechanism of Corporate Social Responsibilt in United States and Mainland China. EJBO Electronic Journal of Business Ethics and Organization Studies: 15-26

[37] Wibisono, Yusuf.(2007) Membedah Konsep dan Aplikasi CSR. Gresik: Fascho Publishing. 